Special issue of the 3rd International Conference on Computational and Experimental Science and Engineering (ICCESEN 2016)

\title{
Interaction Between Grapefruit Juice and Drugs
}

\author{
A. SAY, A. AyAr AND D. ÇAKIR \\ Sabuncuoğlu Şerefeddin Vocational School of Health Services, Amasya University, Amasya, Turkey
}

\begin{abstract}
Clinically significant grapefruit juice-drug interactions are an interesting development in the last ten years of research process in the scope of drug interactions. In 1989 a group of Canadian researchers found incidentally that grapefruit juice, used as a carrier system, interacts with some calcium channel blockers, while applying alcohol during a study on alcohol-drug interactions, and presented it in Lancet as a "short report". In this report it is stated that this effect of grapefruit juice is specific and there is no similar interaction with orange juice. The grapefruit juice interactions with drugs and changes in drug pharmacokinetics, individual responses to grapefruit juice in the relationship between the drug concentration and the effect began to gain a larger clinical significance. Drugs interacting with grapefruit juice are metabolized by cytochrome P450 enzyme system in liver or intestinal section. Flavonoids contained in grapefruit juice inhibit the enzyme, bind as a substrate to the enzyme system and disrupt its bioavailability. Naringin is an essential bioflavonoid in the grapefruit juice. Naringin is not a potent inhibitor of cytochrome P450, but it is partly metabolised to "Naringenin" by intestinal bacteria. This substance is a powerful inhibitor of cytochrome P450 and it is believed by some researchers, that these are components responsible for the effect of grapefruit juice. In 2008 the number of drugs that can cause danger when taken together with grapefruit was 17. It has been reported that this number has risen to 43 in 2012 . However, while the research of the possible effects of other not yet identified components of the grapefruit juice is still in progress, FDA has begun to put cautionary statement to many drug prescriptions.
\end{abstract}

DOI: 10.12693/APhysPolA.132.1030

PACS/topics: 42.62.Be

\section{Introduction}

Grapefruit (Citrus paradisi) is a kind of non-leafing fruit, which is cultivated in many kinds and cultural forms from the family of Rutaceae. Botanist James Macfadyen was the first scientific explanatory scientist to describe grapefruit in 1837, distinguishing it from other citrus fruits [1]. According to researches, grapefruit juice or grapefruit with certain medicines may produce harmful side effects [2]. Grapefruit can block an enzyme which metabolizes medication. If the drug is not metabolized, then the level of the drug in the blood can become too high, leading to an adverse effect. The other effect is that grapefruit can block the absorption of drugs in the intestine. If the drug is not absorbed, then not enough of it is in the blood, to have a therapeutic effect [3].

Cytochromes P450 (CYPs) are proteins of the super family containing hemeas cofactor and, therefore, are hemoproteins. The CYP3A4 isoform of cytochrome P450 is located in both the liver and the enterocytes. CYPs are the major enzymes involved in drug metabolism, accounting for about $75 \%$ of the total metabolism. Most drugs undergo deactivation by CYPs, either directly or by facilitated excretion from the body. Also, many substances are bioactivated by CYPs, to form their active compounds [4]. Naturally occurring compounds may also induce or inhibit CYP activity.

For example, bioactive compounds found in grapefruit juice and some other fruit juices, including bergamottin, dihydroxybergamottin, and paradicin-A,

corresponding author; e-mail: arif.ayar@amasya.edu.tr have been found to inhibit CYP3A4-mediated metabolism of certain medications, leading to increased bioavailability and thus, the strong possibility of overdosing [5].

Because of this risk, avoiding grapefruit juice and fresh grapefruits entirely while on drugs is usually advised [7]. The interaction between grapefruit juice and other medication depends on the individual drug, and not the class of the drug.

Drugs that interact with grapefruit juice share three common features: they are taken orally, normally only a small amount enters systemic blood circulation, and they are metabolized by CYP3A4. According to Canadian Medical Association, there is an increase in the number of potential drugs that can interact with grapefruit juice. From 2008 to 2012, the number of drugs known to potentially interact with grapefruit juice, with risk of harmful or even dangerous effects (gastrointestinal bleeding, nephrotoxicity), has increased from 17 to 43 [9].

Furanocoumarins irreversibly inhibit cytochrome P450 metabolizing enzyme called CYP3A4. CYP3A4 is a metabolizing enzyme for almost $50 \%$ of drugs, and is found in the liver and small intestinal epithelial cells [11]. As a result, many drugs are impacted by consumption of grapefruit juice. When the metabolizing enzyme is inhibited, less of the drug will be metabolized by it in the epithelial cells. A decrease in drug metabolism means more of the original form of the drug could pass unchanged to systemic blood circulation [12]. An unexpected high dose of the drug in the blood could lead to fatal drug toxicity [11].

For example, acetaminophen/paracetamol (Tylenol) concentrations were found to be increased in murine blood by white and pink grapefruit juice, with the white juice acting faster [13]. Interestingly, "the bioavailability 
of paracetamol was significantly reduced following multiple GFJ administration" in mice and rats. This suggests that repeated intake of grapefruit juice reduces the efficacy and bioavailability of acetaminophen/paracetamol in comparison to a single dose of grapefruit juice, which conversely increases the efficacy and bioavailability of acetaminophen/paracetamol [12, 13]. Tassaneeyakul et al. reported the effect of grapefruit juice intake on the disposition of omeprazole and its primary metabolites, following a single oral dose, to 13 healthy volunteers, two of whom being poor metabolisers for cytochrome P450 (CYP) 2C19 [14].

TABLE I

List of drugs affected by grapefruit juice [15].

\begin{tabular}{|c|c|c|}
\hline Drug class & $\begin{array}{l}\text { Major } \\
\text { interactions }\end{array}$ & $\begin{array}{l}\text { Minor } \\
\text { interactions }\end{array}$ \\
\hline Antiarrhythmic agents & $\begin{array}{l}\text { Amidarone } \\
\text { Dronedarone }\end{array}$ & \\
\hline Antihistamines & $\begin{array}{l}\text { Terfenadine } \\
\text { Diphenhy- } \\
\text { dramine } \\
\text { Astemizole }\end{array}$ & \\
\hline $\begin{array}{l}\text { Calcium channel } \\
\text { antagonists }\end{array}$ & & $\begin{array}{l}\text { Felodipine } \\
\text { Nicardipine } \\
\text { Nifedipine } \\
\text { Nimodipine } \\
\text { Nisoldipine } \\
\text { Isradipine }\end{array}$ \\
\hline $\begin{array}{l}\text { Cholesterol- lowering drugs } \\
\text { aka Statins (HMG-CoA re- } \\
\text { ductase inhibitors) }\end{array}$ & $\begin{array}{l}\text { Simvastatin } \\
\text { Lovastatin }\end{array}$ & $\begin{array}{l}\text { Atorvastatin } \\
\text { Cerivastatin }\end{array}$ \\
\hline $\begin{array}{l}\text { Cough suppressant/ } \\
\text { NMDA antagonist }\end{array}$ & $\begin{array}{l}\text { Dextromethor- } \\
\text { phan }\end{array}$ & \\
\hline Erectile dysfunction drugs & & $\begin{array}{l}\text { Sildenafil } \\
\text { Tadalafil } \\
\text { Vardenafil }\end{array}$ \\
\hline HIV protease inhibitors & & $\begin{array}{l}\text { Saqunavir } \\
\text { Ritonavir } \\
\text { Nelfinavir } \\
\text { Amprenavir }\end{array}$ \\
\hline Hormones & & $\begin{array}{l}\text { Ethinylestradiol } \\
\text { Methylpredni- } \\
\text { solone }\end{array}$ \\
\hline Immunosuppressants & & $\begin{array}{l}\text { Ciclosporin } \\
\text { Tacrolimus } \\
\text { Sirolimus } \\
\text { mercaptopurine }\end{array}$ \\
\hline $\begin{array}{l}\text { Sedatives, hypnotics } \\
\text { and anxiolytics }\end{array}$ & Buspirone & $\begin{array}{l}\text { Triazolam } \\
\text { Midazolam } \\
\text { Diazepam } \\
\text { Zaleplon } \\
\text { Alprazolam } \\
\end{array}$ \\
\hline Otherpsychotropics & & $\begin{array}{l}\text { Carbamazepine } \\
\text { trazodone } \\
\text { quetiapine } \\
\text { Fluvoxamine } \\
\text { Nefazodone }\end{array}$ \\
\hline Other miscellaneous drugs & Cisapride & \\
\hline
\end{tabular}

\section{Conclusions}

Grapefruit juice may be the first drug-interacting fruit juice documented, but apple and orange juices have been also implicated in interfering with etoposide, a chemotherapy drug, some beta blocker drugs, used to treat high blood pressure, and cyclosporine, taken by transplant patients to prevent rejection of their new organs. Unlike other fruits, grapefruit contains a large amount of naringin, and it can take up to 72 hours before the effects of the naringin on the CYP3A4 enzyme are seen. This is problematic as a $4 \mathrm{oz}$ portion of grapefruit contains enough naringin to inhibit the metabolism of substrates of CYP3A4. Juice of limes and Seville oranges can also inhibit drug metabolism, however, as can apple juice with some drugs [15]. A 4-hour interval between grapefruit consumption and the medication should suffice. For drugs recently sold on the market, drugs have information pages (monographs) that provide information on any potential interaction between a medication and grapefruit juice [11]. Because there is a growing number of medications that are known to interact with grapefruit juice, patients should consult a pharmacist or physician before planning to take grapefruit juice with their medications.

\section{References}

[1] S.U. Mertens-Talcott, I. Zadezensky, W.V. De Castro, H. Derendorf, V. Butterweck, J. Clinical Pharmacol. 46, 1390 (2006).

[2] D.G. Bailey, G. Dresser, J.M.O. Arnold, Canadian Med. Assoc. J. 185, 309 (2012).

[3] S. Mitchell, Why grapefruit and medication can be a dangerous mix, in: Consumer Reports, retrieved 19 February 2016.

[4] F.P. Guengerich, Chem. Res. Toxicol. 21, 70 (2008).

[5] D.G. Bailey, G.K. Dresser, Am. J. Cardiovascular Drugs 4, 281 (2004).

[6] N. Karpuz, B. Mavi, Acta Phys. Pol. A 130, 304 (2016).

[7] R. Bressler, Geriatrics 61, 12 (2006).

[8] İ. Akkurt, R.B. Ermiş, P. Başa, K. Günoğlu, Acta Phys. Pol. A 128, 34 (2015).

[9] D.J. Greenblatt, K.C. Patki, L.L. von Moltke, R.I. Shader, J. Clin. Psychopharmacol. 21, 357 (2001).

[10] F. Kılınç, N. Karpuz, B. Çetin, Acta Phys. Pol. A 130, 318 (2016).

[11] M. Pirmohamed, British Med. J. 346, 1 (2013).

[12] S. Agosti, L. Casalino, G. Bertero, A. Barsotti, C. Brunelli, S. Morelloni, Am. J. Emergency Med. 30, 248 (2012).

[13] A. Dasgupta, M.A. Reyes, S.A. Risin, J.K. Actor, J. Med. Food 11, 795 (2008).

[14] W. Tassaneeyakul, S. Vannaprasaht, Y. Yamazoel, British J. Clinical Pharmacol. 49, 139 (2000).

[15] B. Nicholas, Experts Reveal the Secret Powers of Grapefruit Juice, in: The New York Times, retrieved 21 March 2006. 